\title{
Yield and Nutritional Status of Mungbean as Influenced by Molybdenum and Phosphorus
}

\author{
Junaid Ahmad ${ }^{1 *}$, Shazma Anwar ${ }^{1}$, Anwar Ali Shad ${ }^{2}$, Fazal Yazdan Saleem Marwat ${ }^{3}$, Hamida Bibi ${ }^{4}$, Farhan \\ Ahmad $^{1}$, Wajia Noor ${ }^{5}$ and Bibi Sadia ${ }^{5}$
}

${ }^{1}$ Department of Agronomy, Faculty of Crop Production Sciences, The University of Agriculture, Peshawar, Khyber Pakbtunkhwa, Pakistan; ${ }^{2}$ Department of Agricultural Chemistry, Faculty of Nutrition Sciences; ${ }^{3}$ Senior Scientific Officer, Oilseeds Research Program NARC Islamabad, Pakistan; ${ }^{4}$ Department of Soil and Environmental Science, The University of Agriculture Peshawar, Khyber Pakbtunkhwa, Pakistan; ${ }^{5}$ Department of Botany, Sardar Bahadur Khan Women's University Quetta, Pakistan.

Abstract | Legumes are most important crops after cereals having provide a range of essential nutrients and nitrogen fixation for soil fertility particularly for the subsequent crops and yield productivity. In order to improve the nutritional profile of mungbean a study was arranged at Agronomy Research Farm, Agriculture University of Peshawar in summer season 2018. The objectives of the study is to find out impact of different doses of molybdenum and phosphorus application on productivity and nutrients status of mungbean ( Vigna radiate $\mathrm{L}$.). The trial was laidout in randomized complete block design having three replicates. The experimental findings revealed that all the nutritional attributes and yield were significantly influenced with molybdenum and phosphorus addition except potassium uptake by grains and straw. Higher seed yield $\left(772.45 \mathrm{~kg} \mathrm{ha}^{-1}\right)$ and harvest index $(26.18 \%)$ with application of $1.5 \mathrm{~kg} \mathrm{ha}^{-1}$ molybdenum while more protein content $(21.91$ $\%)$, carbohydrates $(60.36 \%)$, nitrogen content in grain $(3.76 \%)$ and straw $(1.10 \%)$, phosphorus uptake in grain $(0.380 \%)$ and straw $(0.186 \%)$ was achieved with molybdenum applied at rate of $2.5 \mathrm{~kg} \mathrm{ha}^{-1}$. Whereas in case of phosphorus use maximum seed yield $\left(810.88 \mathrm{~kg} \mathrm{ha}^{-1}\right)$ and harvest index $(26.92 \%)$ was observed with $60 \mathrm{~kg} \mathrm{ha}^{-1} \mathrm{P}$ application while highest protein content $(22.08 \%)$, carbohydrates $(60.37 \%)$, nitrogen content in grain $(3.60 \%)$ and straw $(1.19 \%)$, phosphorus uptake in grain $(0.418 \%)$ and straw $(0.21 \%)$, potassium uptake in grain $(1.96 \%)$ and straw (1.30\%) was achieved with $\mathrm{P}$ applied at $90 \mathrm{~kg} \mathrm{ha}^{-1}$. Higher doses of phosphorus and molybdenum enhance all the quality attributes of mungbean. It concluded from the experimental findings that mungbean crop with $\left(1.5 \mathrm{~kg} \mathrm{ha}^{-1} \mathrm{Mo}\right.$ and $\left.60 \mathrm{~kg} \mathrm{ha}^{-1} \mathrm{P}\right)$ for seed yield and $(2.5 \mathrm{~kg}$ $\mathrm{ha}^{-1} \mathrm{Mo}$ and $90 \mathrm{~kg} \mathrm{ha}^{-1} \mathrm{P}$ ) for enhancement of nutrients uptake of mungbean performed better than other doses and thus recommended for higher productivity and qualitative attributes in agro climatic condition of study area.

Received | October 12, 2020; Accepted | January 04, 2021; Published | March 03, 2021

*Correspondence | Junaid Ahmad, Department of Agronomy, Faculty of Crop Production Sciences, The University of Agriculture, Peshawar, Khyber Pakhtunkhwa, Pakistan; Email: Junaid.agri@aup.edu.pk

Citation | Ahmad, J., S. Anwar, A.A. Shad, F.Y.S. Marwat, H. Bibi, F. Ahmad, W. Noor and B. Sadia. 2021. Yield and nutritional status of mungbean as influenced by molybdenum and phosphorus. Pakistan Journal of Agricultural Research, 34(1): 144-153.

DOI | http://dx.doi.org/10.17582/journal.pjar/2021/34.1.144.153

Keywords | Carbohydrates, Molybdenum, Mungbean, Protein, NPK uptake

\section{Introduction}

$\mathrm{F}$ ood security is threatened to our country and faced by agriculturists. For this food items in higher quantity with good quality are needed to be formed. Amongst food crops, pulses are playing a significant role in achieving food security (Padhi and Pattanayak, 2018). Pulses due to nutritional status 
contribute in improving human health by lowering the risk of different types of diseases like diabetes, obesity and cardiovascular diseases (Vega et al., 2010). Demand of pulse crops are increasing due to increasing population rate in Pakistan. Pulses are the second most important crops after cereals. Mungbean (Vigna radiata L.) is a short duration legume crop. It contains high protein content $(24 \%)$ with good digestibility compared with other pulse crops (Ali et al., 2010). Mungbean is used as food, fodder as well as green manure crop (Sarwar et al., 2004). It is a short duration crop and tolerant to drought that can survive under hostile environmental scenario and thus effectively grown in rainfed zones (Anjum et al., 2006). Mung bean is an important and major conventional kharif legume crop grows in Pakistan (Khattak et al., 2004). In Pakistan mungbean was grown about 133 thousand hectares with total production of 102 thousand tons, while in KPK it was grown about 9 thousands hectares with average productivity of 06 thousand tons (MNFSR, 2017).

In legume crops micronutrients play a vital role and positive response for achieving higher yield through biologicalnitrogenfixationand theirpositiveinfluenced on plant growth. The deficiency of micronutrients effects plant growth and yield. A trace element molybdenum (Mo) is necessary for development of animals and plants and other biological organisms (Westermann, 2005). Molybdenum performs vital role in plant growth and crucial for nitrogenase enzymatic activity and nitrate reductase. Molybdenum required required by rhizobium (nitrogen fixing bacteria) for biological nitrogen fixation as it's a part of nitrogenase enzymes (Westermann, 2005). Legumes required Mo for protein synthesis through the nitrate reductase (Kaiser et al., 2005). In root nodules of legumes molybdenum is also required for the fixation of nitrogen by the rhizobium bacteria. Molybdenum as part of nitrogenase enzymes is required for the conversion of atmospheric nitrogen into ammonium nitrogen. Therefore, in legumes the reason of molybdenum deficiency is more than other crops (Bailey and Ladlaw, 2000). In nutrient deficient soil molybdenum application enhances formation of nodules and thus for nitrogen fixation (Rahman et al., 2008). Molybdenum performed positively for enhancing quantity, quality and nodule formation in legume crops. Application of molybdenum into the soils increases the contents of potassium, phosphorus and crude protein (Anonymous, 2005).
Most of agricultural land of Pakistan are basically alkaline and calcareous in nature. Generally, 95\% of Pakistani soils have deficiency of phosphorous availability (Nisar et al., 2010). Phosphorous deficiency can cause severe reduction in productivity of mungbean crop in early stage of development (Yadav et al., 2017). Phosphorous use efficiency is reduced due to continuous cultivation although $\mathrm{P}$ should be applied in sufficient amount to fields. In macronutrients phosphorus plays a leading role and important for optimum production. It is clearly verified statement from science that for every type of life growth phosphorous plays major role (Ryan et al., 2012). Different factors like poor soil fertility, weeds and insect pest infestation and inadequate application of fertilizer are the main reasons for productivity of mungbean crop (Khan et al., 2015). Application of fertilizers at proper timing through proper method in balanced ratio shows positive response for higher productivity (Alam et al., 2002).

Keeping in view the importance of molybdenum and phosphorus on yield productivity and nutrient uptake of mungbean, the current experiment was planned to explore the best combination of molybdenum and phosphorus fertilizer for improving productivity of mungbean.

\section{Materials and Methods}

A field experiment entitled with "Yield and nutritional status of mungbean as influenced by molybdenum and phosphprus" was assessed at Agronomy Research Farm, Agriculture University Peshawar in Kharif season summer 2018. Sowing was done at second July whereas harvesting was performed at $25^{\text {th }}$ September. The study was carried out in randomized complete block design and replicated thrice. Plot size of $3 \mathrm{~m} \mathrm{x}$ $1.8 \mathrm{~m}$ having 6 rows with row to row distance of $30 \mathrm{~cm}$ and plant to plant distance of $10 \mathrm{~cm}$ was maintained. Various doses of molybdenum and phosphorus was used during the trial. With objectives to find out impact of different molybdenum levels $(0,0.5,1.5$ and $\left.2.5 \mathrm{~kg} \mathrm{ha}^{-1}\right)$ and phosphorus levels $(0,30,60$ and 90 $\mathrm{kg} \mathrm{ha} \mathrm{h}^{-1}$ ) application. Treatment were compared with each other and applied to their respective plots. Single super phosphate and sodium molybdate was used as a source for phosphorus and molybdenum. Variety used Ramzan-92 of mungbean was grown at the rate of 25 $\mathrm{kg} \mathrm{ha}^{-1}$ during trial and spread with the help of seed drill. Initial dose of nitrogen was used $25 \mathrm{~kg} \mathrm{ha}^{-1}$. In 
whole season three irrigations were applied to field, $1^{\text {st }}$ irrigation was applied after seven days sowing of crop, second irrigation before flowering stage and third was done at pods filling stage. Water requirements for the particular crop were fulfilled by supplying over surface irrigation in addition to rainfall.

\section{Molydenum and phosphorus application}

Sodium molybdate and (SSP) used as source for molybdenum and P. For even distribution of molybdenum levels in field, sodium molybdate was mixed with soil ( $1 \mathrm{~g}$ sodium molybdate with $5 \mathrm{~g}$ of soil) and then applied through band placement on single side of each row at sowing time. While all the mentioned phosphorous levels were applied at the time of sowing.

\section{Climate of the site}

The-climatic condition of the site area is semiarid. The experimental site is located at $34.01^{\circ}-\mathrm{N}$ latitude and $71.35^{\circ}$-E longitude, at an altitude of $350 \mathrm{~m}$ above sea level in Peshawar valley. Soil of the experimental site is clay/silt loam with low level of organic matter (0.87\%), phosphorus $\left(6.57 \mathrm{mg}^{-\mathrm{kg}^{-1}}\right)$, potassium (121 $\left.\mathrm{mg}-\mathrm{kg}^{-1}\right)$, alkaline ( $\mathrm{pH}$ 8.2) while nature of soil is calcareous. Other soil physiochemical properties were derived and given in Table 1 (Amanullah et al., 2009).

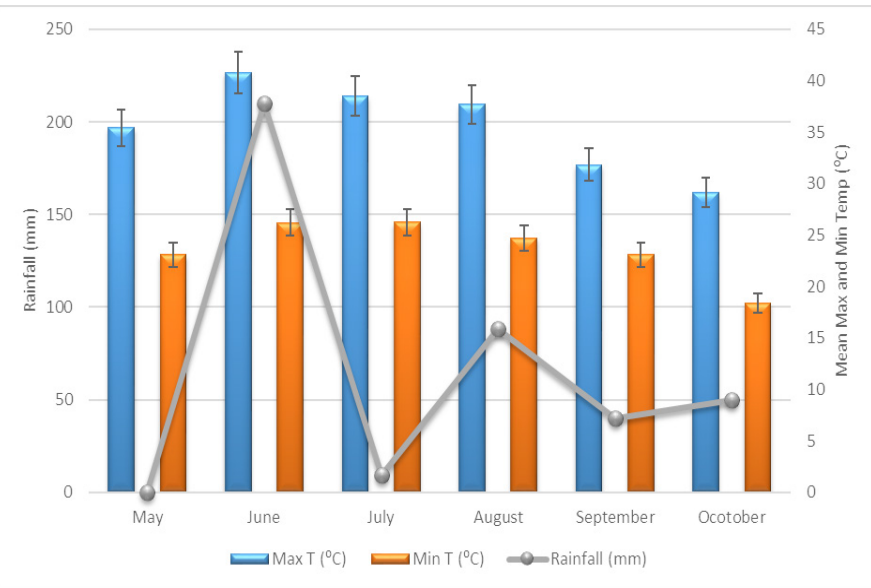

Rainfall and temperature data from May 2018 to October 2018.

\section{Data studied}

Data were taken on seed yield by harvesting central four rows of each plot. The harvested rows were bundled and sundried in open field for ten days. The bundles were weighed, sundried, threshed and samples of grains were taken and weighed with weighing balance and transformed to $\mathrm{kg} \mathrm{ha}{ }^{-1}$ through certain formula. Crop harvest index was measured by dividing economic yield on biomass yield while multiplying with 100 to achieve the value in \%. Grain nitrogen content and straw nitrogen content were determined via Kjeldahl process (Bremmer and Mulvaney, 1996). Sample seeds was grinded with sieved from 0.2 $\mathrm{mm}$ sieve for getting the clear and fine powder for nitrogen determination contents. The sample seed powder of $0.2 \mathrm{~g}$ in the presence of digestion mixture and digested with concentrated $\mathrm{H}_{2} \mathrm{SO}_{4}(3 \mathrm{ml})$ at temperature of $350^{\circ} \mathrm{C}$ till the light greenish color of the samples appeared. The mixture was diluted upon cooling. $20 \mathrm{ml}$ of the diluted digested was distilled with $40 \% \mathrm{NaOH}$ solution and mixed indicator, and then titrated against $\mathrm{HCl}$ solutions, and calculation was made after adjusting for blank reading. Seed and straw phosphorus and potassium content were also determined in the laboratory of the university as per suggested protocol by (Kadwe et al., 1974). Protein content was determined by Kjeldhal method (AOAC, 1990). The percentage of nitrogen was calculated as under:

$N(\%)((V 1-V 2) \times 14.01 \times 0.5) /($ Sample in $m g) \times 100$

V1= Titration reading of sample, V2 = Titration reading of blank, 14.01 = Atomic weight of Nitrogen. The crude protein was determined for seed samples by multiplying the nitrogen content of the sample by 6.25 .

Table 1: Pre-sowing soil physico-chemical properties (O$30 \mathrm{~cm}$ depth).

$\begin{array}{lll}\text { Soil properties } & \text { Unit } & \text { Value } \\ \text { Clay } & \% & 12.5 \\ \text { Silt } & \% & 49.7 \\ \text { Sand } & \% & 36.8 \\ \text { Textural class } & - & \text { Slit loam } \\ \mathrm{pH} & - & 7.78 \\ \text { EC } & \mathrm{d} \mathrm{S} \mathrm{m}^{-1} & 0.16 \\ \text { Organic matter } & \% & 0.83 \\ \text { Total nitrogen } & \% & 0.067 \\ \text { Phosphorus } & \mathrm{mg} \mathrm{kg}^{-1} & 2.33 \\ \text { Potassium } & \mathrm{mg} \mathrm{kg}^{-1} & 106.3\end{array}$

\section{Statistical analysis}

All the taken data were statistically examined over the appropriate technique for the analysis of variance specifically for the design of randomized complete block. Average of data were linked by means of LSD test at $\mathrm{P}<0.05$ level of probability (Jan et al, 2009). 
This is not SJA style. There is difference in report and manuscript. Follow SJA style and improve the standard of writing for each section.

\section{Results and Discussion}

\section{Seeds yield $\left(\mathrm{kg} \mathrm{ha}^{-1}\right)$}

Seeds yield is a final production of every crop in study and based on several features. The present study indicated that seed yield varied significantly with different application treatments of molybdenum and phosphorus Table 2. The maximum seed yield was noted in plots gaining with $1.5 \mathrm{~kg}$ of $\mathrm{Mo} \mathrm{ha}^{-1}$ followed by $2.5 \mathrm{~kg}$ of $\mathrm{ha}^{-1}$ (Figure 4). This growth in yield of seed could be because of molybdenum that improved rhizobium activity, nitrogen fixation, and vegetative growth and yield components in mungbean. Need critical discussion. Review and discussion are two different things. Molybdenum has a prominent role in the effectiveness of the nodules, which made the soil environment favorable for the absorption of other nutrients from the soil, promoted nitrogen fixation and played a positive role in flowering, pod formation and other performance attributes (Chattarjee and Bhandyopadhy, 2017). These consequences are in agreement with those conveyed by Pattanayak et al. (2000) and Anwar et al. (2018) who confirmed that the yield of mung bean grain increased with increasing molybdenum levels compared to the control. Similarly, in form P, more seed production of fertilized plots $60 \mathrm{~kg}$ of $\mathrm{P} \mathrm{ha}^{-1}$ was achieved, tailed by fertilized treatments having $90 \mathrm{~kg}$ of $\mathrm{P}$, while seed yield more low was noted in the control plots. The reason for the increase in seed yield with higher phosphorus could be due to the development of the root, the greater absorption of nutrients and a greater accumulation of dry matter during the growth period and the translocation of more photosynthesis to the seed (Ahmad et al., 2018). Phosphorus fertilizer helped the crop create extra seeds and other reproductive measures that eventually subsidized to yield (Rani et al., 2016; Ahmad et al., 2018). The consequences are also in line with Tariq et al. (2007) they showed a more seed production with higher doses of $\mathrm{P}$ to mungbean.

\section{Harvest index (\%)}

The harvest index is image of proportions of seed and biomass production. In the existing discussions, the application of molybdenum and phosphorus responded significantly to the harvest rate of mungbean, while their interaction was not significant Table 2. Treatments received molybdenum $(1.5 \mathrm{~kg}$ $\left.\mathrm{ha}^{-1}\right)$ resulted more harvest index that is on par with molybdenum applied with $2.5 \mathrm{~kg} \mathrm{ha}^{-1}$ (Figure 4). These investigations close conformity of Tahir et al. (2014), they stated that the application of molybdenum is involved in many physiological and phenological features of mungbean, which ultimately responded at a maximum harvest rate. Singh et al. (2014) also found a maximum crop index in mungbean by applying molybdenum over the control. In case of $\mathrm{P}$, treatments gaining with $60 \mathrm{~kg}$ of $\mathrm{P}$ created a maximum harvest index, whereas lower harvest index was detected in plots gaining with a low phosphorus level. The improvement in the harvest index maybe the results due to improvement in the physiological capability to organize photosynthesis and its translocation in organs that have economic value (Nikfarjam et al., 2015). These conclusions are compatible of Ahmed et al. (2018) they determined that HI enlarged through the increase in phosphorus.

Table 2: Shows seed yield, harvest index, protein and carbohydrates content of mungbean as influenced by molybdenum and phosphorus application.

$\begin{array}{lllll}\begin{array}{l}\text { Phosphorus } \\ \left.\mathbf{( k g ~ h a}^{-1}\right)\end{array} & \begin{array}{l}\text { Seed yield } \\ \left.\mathbf{( k g ~ h a}^{-1}\right)\end{array} & \begin{array}{l}\text { Harvest } \\ \text { index (\%) }\end{array} & \begin{array}{l}\text { Protein } \\ \text { \% }\end{array} & \begin{array}{l}\text { Carbohy- } \\ \text { drates }(\%)\end{array} \\ \text { Control } & 558.56 \mathrm{c} & 22.28 \mathrm{~b} & 19.42 \mathrm{~d} & 56.42 \mathrm{~d} \\ 30 & 601.62 \mathrm{bc} & 22.01 \mathrm{~b} & 20.47 \mathrm{c} & 57.39 \mathrm{c} \\ 60 & 810.88 \mathrm{a} & 26.92 \mathrm{a} & 21.12 \mathrm{~b} & 58.59 \mathrm{~b} \\ 90 & 664.35 \mathrm{~b} & 23.05 \mathrm{~b} & 22.08 \mathrm{a} & 60.37 \mathrm{a} \\ \text { LSD } & 84.65 & 3.35 & 0.34 & 0.68 \\ \text { Molybdenum } & \left(\mathrm{kg} \mathrm{ha}^{-1}\right) & & & \\ \text { Control } & 534.95 \mathrm{c} & 20.95 \mathrm{c} & 19.57 \mathrm{~d} & 56.70 \mathrm{~d} \\ 0.5 & 625.23 \mathrm{bc} & 22.74 \mathrm{bc} & 20.35 \mathrm{c} & 57.25 \mathrm{c} \\ 1.5 & 772.45 \mathrm{a} & 26.18 \mathrm{a} & 21.25 \mathrm{~b} & 58.46 \mathrm{~b} \\ 2.5 & 702.78 \mathrm{ab} & 24.38 \mathrm{ab} & 21.91 \mathrm{a} & 60.36 \mathrm{a} \\ \text { LSD } & 84.65 & 3.35 & 0.34 & 0.68\end{array}$

\section{Protein (\%)}

Data regarding protein (\%) content of mungbean is presented in Table 2. Analysis of the data indicated that protein (\%) content of mungbean crop has positively influenced with the combined application of phosphorus and molybdenum while the interaction among molybdenum and phosphorus have also positive impact on protein (\%) content of mungbean. Protein content of mungbean was observed higher with higher dose of phosphorus application. Phosphorus applied dose of $90 \mathrm{~kg} \mathrm{ha}^{-1}$ recorded more protein content i.e. 
$(22.08 \%)$ while in case of no dose of phosphorus applied observed less amount of protein content $\%$ i.e. (19.42\%). Mehboob et al. (2019) stated that protein $\%$ is increased with increasing dose of phosphorus application. This increasing trend might be due to the fact that Phosphorus is vital for development of new tissue and the transfer of the genetic information within the plant from one cell to another during cell formation. Similar results were correlated with the investigations of (Rausch et al., 2001; Mehboob et al., 2019; Gruhun et al., 2000) they stated that phosphorus application recorded enhancing in content of protein (\%) of mungbean. Similarly, in case of molybdenum addition response with increasing trend to increasing levels of molybdenum. Molybdenum dose applied with the rate of $2.5 \mathrm{~kg} \mathrm{ha}^{-1}$ recorded higher trend of protein $\%$ i.e. $(21.91 \%)$ followed by $(21.25 \%)$ with application rate of molybdenum at rate of $1.5 \mathrm{~kg}$ $\mathrm{ha}^{-1}$ while less amount of protein content (19.57\%) was observed with no molybdenum addition. It might be due to fact that molybdenum is essential for nitrogenase activities of most of biotic creatures containing plants also (Graham and Stangoulis, 2005). Normally, molybdenum is a vital micronutrient for bacteria and plants also (Williams and Silva, 2002). Meagher et al. (1991) conveyed the character of molybdenum in typical incorporation of nitrogen by plants is well known, because molybdenum is a fundamental constituent of nitrate reductase and nitrogenase, which resist to the lessening of mineral nitrate and supports for fixative of N2 to NH3. Thus, molybdenum is the basic to nitrogen fixation and increasing the protein content of by legumes.

\section{Carbobydrates (\%)}

Data regarding carbohydrates content of mungbean as influenced by molybdenum and phosphorus application on mungbean crop presented in Table 2 . Analysis of variance indicated that both molybdenum and phosphorus and their combined application performed significantly positive response towards carbohydrates contents (\%) of mungbean crop. Molybdenum application at the rate of $2.5 \mathrm{~kg} \mathrm{ha}^{-1}$ enhance carbohydrates contents $6.05 \%$ more than control treatments. While in case of phosphorus application carbohydrates contents were enhanced by phosphorus almost $12.38 \%$ than no phosphorus treated plots. Improving carbohydrates contents by molybdenum and phosphorus application might be due to molybdenum enhance the nodulated efficiency of mungbean crop, with greater formation of more nodules in numbers it may be able to fix more atmospheric nitrogen as in their roots and forward these efficiencies to the ultimate production of mungbean grains and play a significant role in amino acids formation of the seeds while phosphorus improve the grains capacity and hardness of mungbean seeds. Further it was explained by Mubarak (2005) they reported that nutritional score of mungbean in case of carbohydrates contents it may be increased up to $10-20 \%$ and also by using the FAO/WHO (1973) reference pattern, whereas Tsou et al. (1979) explained that mungbean grains have much sufficient amount of amino acids and other adequate nutritional contents. The results were also in conformity with those of E1Adawy et al. (2003).

\section{Phosphorus concentration in seeds and straw (\%)}

Data status of phosphorus profile in seeds of mungbean were evaluated in Table 3. Analysis of the consequences represents that phosphorus contents in seeds of mungbean were significantly enhanced with phosphorus and molybdenum application to mungbean crop. Analysis shows that phosphorus profile increased with increasing dose of phosphorus (Figure 1). Higher dose of phosphorus shows up to $25 \%$ improvement in mungbean seeds with respect to $\mathrm{P}$ contents while straw phosphorus contents were improved (27.20\%) with enhanced doses of phosphorus. Its potency might be due to fact that more $\mathrm{P}$ application to legume crops will response back to more content of $\mathrm{P}$ in seeds of the different crops because phosphorus plays a significant role for legumes production and seed hardness with quality improvement in grains profile (Naagar et al., 2004) Similarly in case of phosphorus content in straw of mungbean similar trend were found i.e. increasing phosphorus content in mungbean straw with increasing doses of phosphorus addition (Figure 2). Whereas molybdenum also shows a positively response towards improving in straw and seeds phosphorus content of mungbean. Straw and seeds phosphorus content were increased up to $11 \%$ and $10 \%$, respectively when compared with control treatment where no molybdenum was applied. The regulatory effect of phosphorus and molybdenum during carbohydrate metabolism and at the time of photosynthesis in leaves and other plant parts should be considered one of the important and majorly plant limiting factor of plant growth and development particularly when convert to reproductive portion of the plant (Kumawat et al., 2009). The increasing 
doses of phosphorus at these positions of the crops enhanced starch and sucrose ratio of the leaves and other reproductive organs of the plant (Nagar et al., 2008). Khattak et al.(2004) observed more phosphorus contents in legume seeds as they enhance phosphorus doses. Results were also further confirmed by (Singh et al., 1968; Muhammed et al., 2010) they stated that the chemical constituent of mungbean seeds were unevenly distributed with macro nutrient application like phosphorus.

Table 3: Shows grain and straw NPK \% contents as influenced by molybdenum and phosphorus application.

\section{Nitrogen \% Phosphorus \% Potassium \%}

Phosphorus Grain Straw Grain Straw Grain Straw $\left(\mathrm{kg} \mathrm{ha}^{-1}\right)$

0 $2.842 \mathrm{~d} \quad 0.951 \mathrm{~b} \quad 0.333 \mathrm{~d} \quad 0.153 \mathrm{c} \quad 1.863 \mathrm{~d} 1.234 \mathrm{~b}$

$30 \quad 3.133$ c $0.999 a b \quad 0.362$ c 0.160 c 1.903 c $1.239 b$

$\begin{array}{lllllll}60 & 3.391 \mathrm{~b} & 1.076 \mathrm{a} & 0.379 \mathrm{~b} & 0.175 \mathrm{~b} & 1.934 \mathrm{~b} & 1.259 \mathrm{~b}\end{array}$

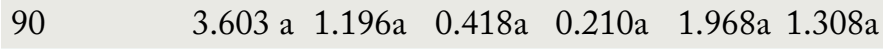

$\begin{array}{llllllll}\text { LSD } & 0.170 & 0.081 & 0.016 & 0.012 & 0.030 & 0.033\end{array}$

Molybdenum ( $\left.\mathrm{kg} \mathrm{ha}^{-1}\right)$

$\begin{array}{lllllll}0 & 2.620 \text { c } & 0.986 \mathrm{c} & 0.360 \mathrm{~b} & 0.166 \mathrm{c} & 1.900 & 1.231\end{array}$

$0.5 \quad 2.954 \mathrm{~b} \quad 1.060 \mathrm{bc} 0.373 \mathrm{ab} 0.169 \mathrm{bc} 1.906 \quad 1.264$

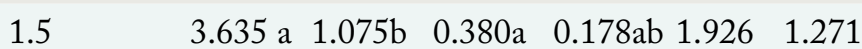

$\begin{array}{lllllll}2.5 & 3.760 \text { a } & 1.101 \mathrm{a} & 0.379 \mathrm{a} & 0.186 \mathrm{a} & 1.936 & 1.273\end{array}$

$\begin{array}{lllllll}\text { LSD } & 0.170 & 0.081 & 0.016 & 0.012 & \text { NS } & \text { NS }\end{array}$
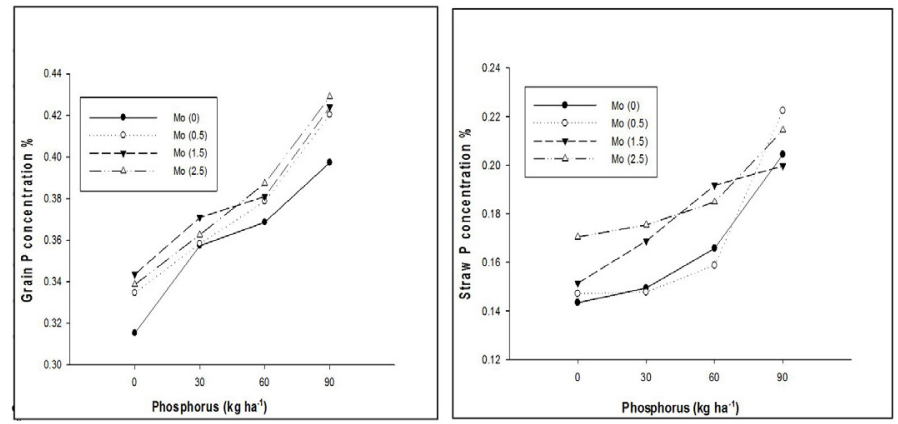

Figure 1: Shows grains and straw $P$ contents as influenced by molybdenum and phosphorus.

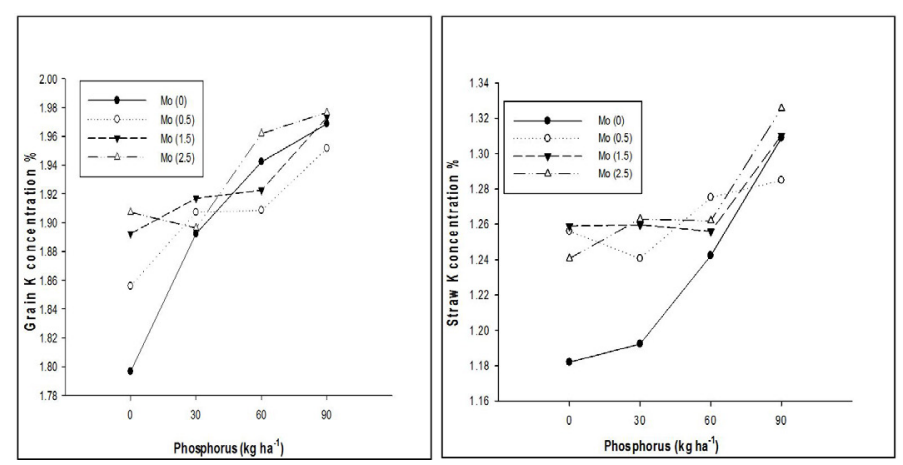

Figure 2: Shows grains and straw $K$ contents as influenced by molybdenum and phosphorus.
Nitrogen concentration in seeds and straw (\%)

Data on the $\mathrm{N}$ content in seeds of mungbean as impacted by the application of molybdenum and phosphorus (Table 3). Analysis proposed that molybdenum, phosphorus and Mo x $\mathrm{P}$ influenced significantly the seeds and straw $\mathrm{N}$ content. A higher seeds $\mathrm{N}$ content was recorded with a higher dose of molybdenum $\left(2.5 \mathrm{~kg} \mathrm{ha}^{-1}\right)$ traced by a molybdenum of $1.5 \mathrm{~kg} \mathrm{ha}^{-1}$, less seeds $\mathrm{N}$ was recorded in controls treatment (Figure 4). In occasion of phosphorus, higher grain $\mathrm{N}$ was noted with $\mathrm{P}$ usage at $90 \mathrm{~kg} \mathrm{ha}^{-1}$ traced by $\mathrm{P}$ at $60 \mathrm{~kg} \mathrm{ha}^{-1}$, whereas minimum was noted in controls (Figure 4). The interactive response of $\mathrm{Mo}$ $\mathrm{x} \mathrm{P}$ displayed a progressive impact on the $\mathrm{N}$ amount of grain and increases with rising rates of $\mathrm{P}$ and $\mathrm{Mo}$. The highest $\mathrm{N}$ of grain was perceived in those plots fertilized by molybdenum at $2.5 \mathrm{~kg} \mathrm{ha}^{-1}$ and $90 \mathrm{~kg} \mathrm{P}$ $\mathrm{ha}^{-1}$. Similarly, with higher dose of molybdenum seeds $\mathrm{N}$ content were enhanced up to (30.32\%) in seeds of mungbean while $(10.43 \%)$ were enhanced in straw of mungbean. Seeds nitrogen content was significantly influenced with molybdenum, phosphorus and Mo $x$ P. Seeds N content was positively improved with increasing levels of molybdenum. Treated plots with greater molybdenum dose of $\left(2.5 \mathrm{~kg} \mathrm{ha}^{-1}\right)$ showed significantly higher $\mathrm{N}$ content. Particularly grain nitrogen contents were enhanced about (21.13\%) whereas straw $\mathrm{N}$ content was improved (20.47\%) with higher dose of phosphorus when compared with control. The possible reason for this might be that molybdenum application significantly enhanced nodules efficiency and activate rhizobium for higher fixation of nitrogen from atmosphere for the plant (Agatise and Tayo, 2004). These outcomes are relation to the discoveries of Nautiyal et al. (2005) they exposed grain $\mathrm{N}$ content was significantly ameliorated with more molybdenum doses. In case of phosphorus, grain $\mathrm{N}$ content was enlarged with growing levels of phosphorus. Higher seeds and straw $\mathrm{N}$ content was recorded with maximum dose of phosphorus application, whereas seed and straw nitrogen content was decreased with lower dose of phosphorus (Figure 3). Phosphorus as energy source had strong effect on chlorophyll content, photosynthesis and other metabolic activities to enhance grain $\mathrm{N}$ content (Alam et al., 2002). Hussain et al. (2012) conveyed $P$ is crucially essential for many physiological functions of plants. Phosphorus application had significant response in the efficiency of root nodules, soil bacteria and play major role in biological nitrogen fixation (Jabbar and Saud, 2012). 
Potassium concentration in seeds and straw (\%)

A significantly and positively response were showed by straw and seed potassium content of mungbean with respect to phosphorus application whereas molybdenum did not play a significant role for improving seeds and straw content of mungbean (Table 3). Statistical analysis of the data indicated that phosphorus applied at higher doses added higher values of potassium in seeds and straw of mungbean. Similarly potassium content were improved about $5.31 \%$ and $5.58 \%$ in grain and straw of mungbean respectively (Figure 2). The analysis shows an increasing trend that both seeds and straw contend of potash were enhanced with increasing doses of phosphorus. These results were in close conformity of with Kumawat et al. (2009) who also shows the increasing trend of mungbean potassium content in seeds and straw. Singh and Kapoor (1992) also explained the same variation in mungbean. These results could be due to the importance of phosphorus which shows a great variation in yield and yield component of mungbean as well as with nutrient uptake of different nutrients because the greater availability of phosphorus may guarantee the availability of other nutrients too. Choudhry et al. (2003) reported that phosphorus application enhances the nutritional uptake of different nutrients while it improves growth and yield of legumes crops.
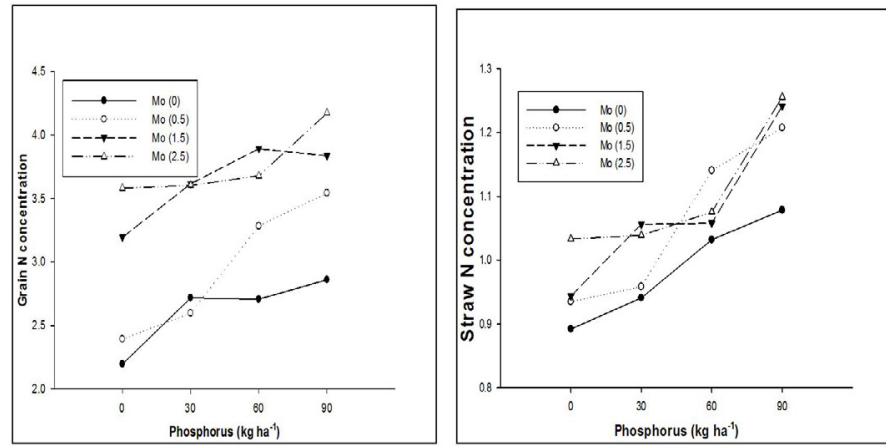

Figure 3: Shows grains and straw $N$ contents as influenced by molybdenum and phosphorus.
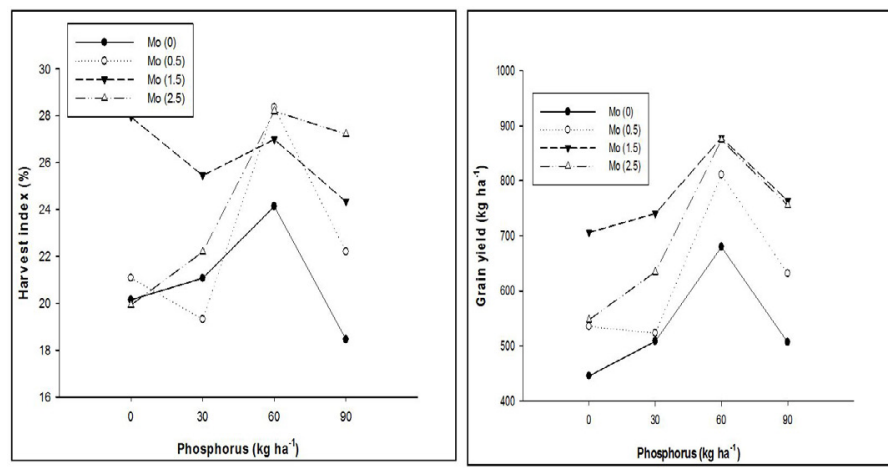

Figure 4: Shows harvest index \% and grain yield of mungbean as influenced by molybdenum and phosphorus.
Conclusions and Recommendations

From the results of the current experiment and their analysis of the data its concluded that legume crops such as mungbean shows a great response towards molybdenum and phosphorus application.Higheryield of seed was recorded with addition of molybdenum at the rate of $1.5 \mathrm{~kg} \mathrm{ha}^{-1}$ and $60 \mathrm{~kg} \mathrm{ha}^{-1}$ phosphorus while all the qualitative attributes of mungbean was recorded higher with highest doses of molybdenum and phosphorus. Therefore, it is concluded from the experimental findings that mungbean crop should be grown for higher seed productivity at $1.5 \mathrm{~kg} \mathrm{ha}^{-1}$ molybdenum and $60 \mathrm{~kg} \mathrm{ha}^{-1}$ phosphorus. While for the enhancement of nutritional indices of mungbean (2.5 $\mathrm{kg} \mathrm{ha} \mathrm{h}^{-1}$ Mo and $90 \mathrm{~kg} \mathrm{ha}^{-1} \mathrm{P}$ ) performed better than other doses and thus recommended for higher productivity and qualitative attributes in agro climatic condition of study area.

\section{Acknowledgments}

The author all extremely thankful to Almighty Allah for giving us the opportunity and knowledge about the concern field to fulfil the ultimate outcomes of the study. After that all the authors are thankful to the home institution for providing us the platform for the experimental study and lab facilities to complete the concern task.

\section{Novelty Statement}

The main purpose of this study was to enhance the yield and nutritional indices of mungbean crop. This study will play a major role for enhancing yield, protein, carbohydrates and other nutritional status of mungbean crop and will be followed for citations and literature review as well.

\section{Author's Contribution}

Junaid Ahmad: Performed and did overall management of the manuscript.

Shazma Anwar: Designed the experiment.

Anwar Ali Shad and Fazal Yazdan Saleem Marwat:

Helps in statistical analysis and result and discussion.

Hamida Bibi: Helps in methodology and lab analysis.

Farhan Ahmad: Help in writing of manuscript.

Wajia Noor and Bibi Sadia: Helps in data entry, data analysis and citations. 
Conflict of interest

The authors have declared no conflict of interest.

\section{References}

Agatise, V.O and T.O. Tayo. 2004. Response of soybean to molybdenum application in Nigeria. Ind. J. Agric. Sci., 64(4): 597-603.

Ahmad, J., F. Ahmad, S. Iqbal, B. Ali, S.M.A. Shah, M. Ali, H. Nawaz, M.W. Abbas and Z. Mahmood. 2018. Response of mungbean yield and yield components into various levels of phosphorous. J. Mat. Sci., 5(1): 1-4. https://doi. org/10.3329/ralf.v5i2.38050

Ahmad. J., F. Ahmad, S. Iqbal, S.M.A. Shah, M. Ali, H. Nawaz, M.W. Abbas and Z. Mahmood, B. Ali, and S. Ali, 2018. Growth and oil yield of sesame as influenced by sulphur and nitrogen. Open. Acc. J. Agric. Res., 3(7): 01-05.

Alam, S.M., S.A. Shah, A. Latif and Z. Iqbal. 2002. Performance of some wheat varieties to fertigation applied phosphorus sources. Pak. J. Soil. Sci., 11(2): 123-125.

Ali, A., A. Amjadi, A. Javed and Y. Muhammad. 2010. Effects of phosphorus in combination with rhizobium inoculation on growth and yield parameters of mung bean. Crop. Environ., 1(1): 53-56.

Ali, M.A., G. Abbas, Q. Mohy-ud-Din, K. Ullah, G. Abbas and M. Aslam. 2010. Response of mung bean (Vigna radiata) to phosphatic fertilizer under arid climate. J. Anim. Plant Sci., 20(2): 83-86.

Amanullah, R.A. Khattak and S.K. Khalil. 2009. Effects of plant density and $\mathrm{N}$ on phenology and yield of maize. J. Plant Nutr., 32: 245-259. https://doi.org/10.1080/01904160802592714

Anjum, M.S., Z.I. Ahmed and C.A. Rauf. 2006. Effect of rhizobium inoculation and nitrogen fertilizer on yield and yield components of mung bean. Int. J. Agric. Biol., 8(2): 238-240.

Anonymous, 2005. Food and Agriculture Organization of the United Nations. http/ www.fao.org.

Anwar, S., Z.U. Rehman, B. Saeed, M. Islam, M.O. Kham and J. Ahmad. 2018. Response of mung bean to organic sources and nitrogen levels. Pure Appl. Biol., 7(2): 692-699.

AOAC, 1990. Association of Official Analytical Chemists. 1990. Official methods of analysis. (Ed. Helvish, K.) $15^{\text {th }}$ Edn. Avington Vergenia.
USA.

Bailey, R. and L.R. Laidlaw. 2000. The interactive effects of $\mathrm{P}, \mathrm{K}$, lime and molybdenum on the growth and morphology of white clover at establishment. Forag. Sci., 16: 69-76. https:// doi.org/10.1046/j.1365-2494.1999.00159.x

Bremmer, J. and M. Mulavanne. 1996. Chapter 37 Nitrogen Total; In methods of soil analysis. Part 3. Chemical methods. SSSA Book Series No. 5.

Chatterjee, R. and S. Bandhyopadhyay. 2017. Effect of boron, molybdenum and biofertilizer on growth and yield of cowpea. J. Saud. Soc. Agric. Sci., 16: 332-336. https://doi.org/10.1016/j. jssas.2015.11.001

Chaudhary, M.I., J. Adu-Gyamfi, H. Saneoka, N.T. Nguyen, R. Suwa, S. Kanai, H. El-Shemy, D.A., Lightfoot and K. Fujita. 2008. The effect of phosphorus deficiency on nutrient uptake, nitrogen fixation and photosynthetic rate in mashbean, mungbean and soybean. Acta Physiol. Plantarum., 30(4): 537-544.

Eady, R.R., 1981. Regulation of nitrogenase activity. In: Current Perspectives in Nitrogen Fixation, eds Gibson, A.H. and Newton, W.E. Canberra city: Australian Academy of Science. pp. 172-182.

El-Adawy, T.A., E.H. Rahma, E.A. Ha, A.A. El-Bedawey and A.E. El-Beltagy. 2003. Nutritional potential and functional properties of germinated mung bean, pea and lentil seeds. Plant Food Hum. Nutr., 58: 1-13. https://doi. org/10.1023/B:QUAL.0000040339.48521.75

FAO/WHO, 1973. Energy and protein requirements. Report of FAO Nutritional Meeting Series No 52. FAO, Rome.

Graham, R.D., and J.R.S. Stangoulis. 2005. Molybdenum and disease. In: Mineral nutrition and plant diseases (eds. Dantoff, L., Elmer, W, . and D. Huber D.eds) St. Paul, MN: APS Press.

Gruhn, P., F. Goletti and M. Yudelman. 2000. Integrated nutrient management, soil fertility and sustainable agriculture: Current issues and future challenges. International Food Policy Research Institute, Washington DC.

Hussain, A., A. Ali and I.R. Noorka. 2012. Effect of phosphorus with and without rhizobium inoculation in nitrogen and phosphorus concentration and uptake by Mungbean (Vigna radiata L). J. Agric. Res., 50(1): 49-57.

Jabbar, B.K.A and H.M. Saud. 2012. Effects of phosphorus on biological nitrogen fixation in 
soybean under irrigation using saline water Glob. J. Sci. Front. Res. Agric. Biol., 12(1): 1-10. Jan, M.T., P. Shah, P.A. Hollington, M.J. Khan and Q. Sohail. 2009. Agri. Res. Des. Analysis. A monograph. Agric. Uni. Pesh. Pak.

Kadwe, R.S., K.K. Thakare and N.N. Badhe. 1974. A note on the protein content and mineral composition of twenty-five varieties of pulses. Indian J. Nutr. Diet., 11: 83-85.

Kaisar,B.N., K.L.Gridley,J.N.Brady,T.Phillips and S.D. Tyerman. 2005. The role of molybdenum in agricultural plant production. Annl. Bot., 96: 745-754. https://doi.org/10.1093/aob/mci226

Khan, K., and V. Prakash. 2014. Effect of rhizobial inoculation on growth, yield, nutrient and economics of summer Urd bean in relation to zinc and molybdenum. Int. J. Adv. Res., 1(1): 1-10.

Khan,A., S.Anwar and M.Z.Afridi.2015.Response of mungbean (Vigna radiata L.) Cultivars to various levels of phosphorous application in agro climatic condition of Peshawar. Int. J. Agric. Environ. Res., 1(2): 68-72.

Khattak, G.S.S., M. Ashraf and M.S. Khan. 2004. Assessment of genetic variation for yield and yield components in mungbean using generation mean analysis. Pak. J. Bot., 36(3): 583-588. https://doi.org/10.1111/j.16015223.2001.00211.x

Kumawat, N., R. Kumar and O.P. Sharma. 2009c. Nutrient uptake and yield of mungbean [Vigna radiata (L.) Wilczek] as influenced by organic manure, PSB and Phosphorus fertilization. Environ. Ecol., 27 (4B): 2002-2005.

Meagher, W. R., M. Johnson and P. R. Stout. 1991. Molybdenum requirement of leguminous plants supplied with fixed nitrogen. Plant. Physiol., 27(2): 623-629. https://doi.org/10.1104/ pp.27.2.223

Mehboob, M., S. Anwar, J. Ahmad, I. Ullah, I. Nawaz,M.A.Khan,A.M.Ali and J.Akbar.2019. Biofertilizer with phosphorus; a sustainable and eco-friendly approach for enhancing mungbean growth, productivity and protein content in changing climatic scenario. Int. J. Biosci., 15(5): 387-393.

MNFSR, 2017. Agriculture statistic of Pakistan. Ministry of national food security and research. Federal bureau of statistics, economics survey of Pakistan.

Mubarak, A.E., 2005. Nutritional composition and anti-nutritional factors of mung bean seeds (Phaseolus aureus) as affected by some home traditional processes. Food. Chem., 89: 489-495. https://doi.org/10.1016/j. foodchem.2004.01.007

Mudler, E.G., K. Bakema, K. and W.L. Van Veen, 1959. Molybdenum in symbiotic nitrogen fixation and in nitrate assimilation. Plant Soil., 10: 319-334. https://doi.org/10.1007/ BF01666208

Muhammed, T., S. Manohar and L. Junna. 2010. Polyphenols of mung bean (Phaseolus aureus L.) cultivars differing in seed coat color. J. New Seeds, 4: 369-379. https://doi.org/10.1080/152 2886X.2010.520146

Muhammad, D., A.H. Gurmani and M. Khan. 2010. Effect of phosphorus and rhizobium inoculation on the yield and yield components of mung bean under the rainfed conditions of D.I. Khan. Sarhad J. Agric., 20(4): 575-584.

Naagar, K.C. and N.L. Meena. 2004. Effect of phosphorus, sulfur and phosphate solubilizing bacteria on yield components, yield and quality of clusterbean Cyamopsis tetragonoloba (L.). Leg. Res., 27: 27-31.

Nagar, V., L.P. Godambe and R. Shahshidar. 2008. Development of microbiologically safe mung bean sprouts usingcombination treatment of sodium hypochlorite and gammaradiation. Int. J. Food. Sci. Tech., 51(2): 595-601.

Nautiyal N., S. Singh and C. Chatterjee. 2005. Seed reserves of chickpea in relation to molybdenum supply. J. Sci. Food. Agric., 85: 860-864.

Nikfarjam, S.G. and H. Aminpanah. 2015. Effect of phosphorus fertilization and pseudomonas fluoresces strains on the growth and yield of faba bean (Vicia faba). 33(4): 15-21. https://doi. org/10.4067/S0718-34292015000400003

Nisar, A., M.T. Saleem and I.T. Twyford. 2010. Phosphorous research in Pakistan; A review. In Proc. Symp. on the role of phosphorous in crop production. Islamabad, Pakistan. pp. 59-92.

Padhi, P.P. and S.K. Pattanayak. 2018. Effect of lime coating and molybdenum seed treatment on nodulation, growth and yield of different pulses. Int. J. Curr. Microbiol. App. Sci., 7(2): 1417-1426. https://doi.org/10.20546/ ijcmas.2018.702.171

Parker, M.B and H.B. Harris. 1977. Yield and leaf nitrogen of nodulating and nonnodulating soybeans as affected by nitrogen and 
molybdenum. Agron. J., 69: 551-554. https:// doi.org/10.2134/agronj1977.00021962006900 $040007 x$

Pattanayak, S.K., D. Das, M.R. Jena and R.K. Nayak.2000. Seed treatment of green gram with molybdenum and cobalt: Effect on nodulation, bio-mass production on $\mathrm{N}$ uptake in an Acid Soil. J. Ind. Soc. Soil. Sci., 48: 769-773.

Rahman, M.M., M.M.H. Bhuiyan, G.N.C. Sutradhar, M.M. Rahman and A.K. Paul. 2008. Effect of phosphorus, molybdenum and rhizobium inoculation on yield and yield attributes of mung bean. Int. J. Sustain. Crop. Prod., 3(6): 26-33.

Rani, M., P. Ved and K. Khalil. 2016. Response of mung bean to phosphorus, sulphur and PSB during summer season. Agric. Sci. Digest., 36(2): 146-148. https://doi.org/10.18805/asd. v36i2.10637

Rausch, C., P. Daram, S. Brunner, J. Jansa, M. Laloi and, G. Leggewie. 2001. A Phosphate transporter expressed in arbuscule-containing cells in potato. Nature, 414: 462-470. https:// doi.org/10.1038/35106601

Ryan, J., H. Ibrikci, A. Delgado, J. Torrent, R. Sommer and A. Rashid. 2012. Significance of phosphorus for agriculture and the environment in the West Asia and North Africa Region. Adv. Agro., 114(4): 91-153. https://doi.org/10.1016/ B978-0-12-394275-3.00004-3

Sarwar, G., M.S. Sadiq, M. Saleem and G. Abbas. 2004. Selection criteria in F3 and F4 population of mung bean. Pak. J. Bot., 36(2): 297-310.

Singh, B. and R.G. Pareek. 2003. Effect of phosphorus and biofertilizer on growth and yield of mungbean. Ind. J. Pulses Res., 16: 3133.

Singh, S. and K.K. Kapoor. 1992. Effect of inoculation of phosphorus solubilizing microorganisms and an arbuscular mycorrhizal fungus on mungbean grown under natural soil conditions. Mycorrhiza, 7: 249-253. https:// doi.org/10.1007/s005720050188

Singh, S., H.D. Singh and K.C. Sikka. 1968. Distribution of nutrients in the anatomical parts of common Indian pulses. Cereal Chem., 45: 13-18.

Singh, S.S., M.A. Khan and A. Srivastava. 2014. Effect of boron and molybdenum application on seed yield of mungbean. Asian J. Biol. Sci., 9(2): 169-172. https://doi.org/10.15740/HAS/ AJBS/9.2/169-172

Tahir, M., A. Sher and, M.A. Majeed. 2014. Effect of Mo on yield and quality of black gram. Pak. J. Life Soc. Sci., 12(2): 101-105.

Tariq, S., S. Ali and S.S. Ijaz. 2007. Improving nitrogen fixation capacity and yield of mung bean and mash bean by phosphorus management in Pothowar. Sarhad J. Agric., 23(4): 1027-1032.

Tsou, C.S., M.S. Hsu, S.T. Tan and H.G. Park. 1979. The protein quality of mungbean and its improvement.ActaHortic.,93:279-287.https:// doi.org/10.17660/ActaHortic.1979.93.26

Vega, R., G.L. Pina and B.D. Omah. 2010. Minor components of pulses and their potential impacts on human health. Food. Res. Int., 43(2): 461-482. https://doi.org/10.1016/j. foodres.2009.09.004

Westermann, D.T., 2005. Nutritional requirements of potatoes. Am. J. Potato Res., 82: 301-307. https://doi.org/10.1007/BF02871960

Williams, R.J.P. and J.J.R. Frausto da Silva. 2002. The involvement of molybdenum in life. Biochem. Biophys. Res. Commun., 292: 293299. https://doi.org/10.1006/bbrc.2002.6518

Yadav, V.K. and P. Singh. 2017. MSc. thesis. Department of Agri Chemical and Soil Sci. Rajhastan college of Agriculture maharana pratap University of Agriculture and Technology, Udaipur-313001. 